\title{
A DISPOSABLE ROTATING OXYGENATOR CAPABLE OF BEING STERILIZED BY HEAT FOR A HEART-LUNG MACHINE
}

\author{
BY \\ MICHAEL WILSON AND KEITH VOWLES \\ From the Department of Surgery, University of Bristol, Bristol Royal Infirmary
}

(RECEIVED FOR PUbLICATION NOVEMBER 24, 1959)

This rotating oxygenator is of a design differing from other rotating oxygenators in that the large surface area necessary for filming blood at high rates of flow is obtained by using a small number of concentric drums rather than a large number of discs. This makes for simplicity of manufacture and ease of assembly.

The design is such that it can be cast in plastic in three parts and mass produced at small cost. A number of plastics capable of being sterilized by heat are now available; preliminary tests of "araldite" (epoxide resin) suggest that it may be the most suitable for this purpose.

A prototype has been machined out of perspex and has been used to test the design in regard to its oxygenating capacity and its effect on blood cells.

\section{DESCRIPTION OF APPARATUS}

The apparatus consists of three cylinders that fit one inside the other and rotate together on an axis that inclines from the horizontal by about $3^{\circ}$. Each cylinder is open at one end and partially closed at the other. The inner two cylinders are furnished with a wide spiral thread on their outer surfaces; the outer cylinder has no thread. The drums fit snugly one inside the other and there is a space of $1 \mathrm{~cm}$. between them which is maintained by the depth of the thread. A metal band encircles the outer drum near each end; these rest on rollers and are used to rotate the apparatus.

Blood is introduced at the closed end of the inner drum, and runs down to the open end by gravity and over into the middle drum. The action of the spiral thread then conducts it along to the other end of this drum and thence over into the outer drum. The other thread, which is pitched in the opposite direction, then moves the blood along the outer drum to its open end. From here it passes into the stationary arterial reservoir. During its passage through the apparatus the blood is exposed as a thin film over the entire inner surface of each drum in an atmosphere of oxygen. The dimensions of the cylinders are given in Table I. It will be seen that the oxygenating surface is approximately 2 sq. metres.

TABLE I

DIMENSIONS OF CYLINDERS

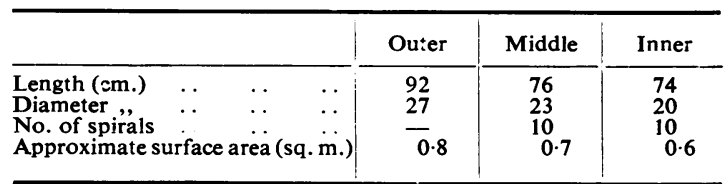

Total surface area, $2 \cdot 1$ square metres.

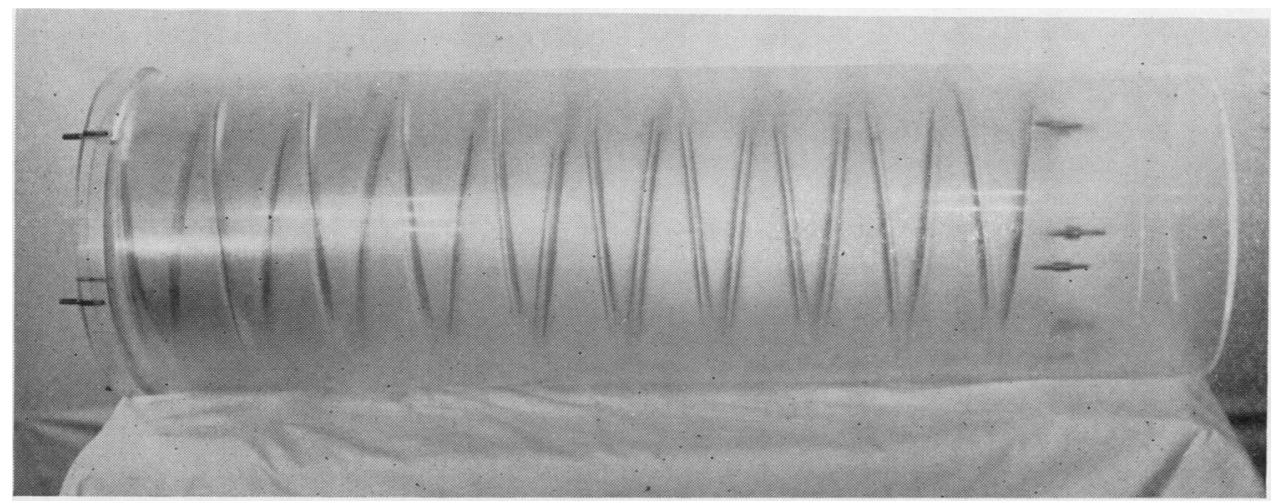

FIc. 1 

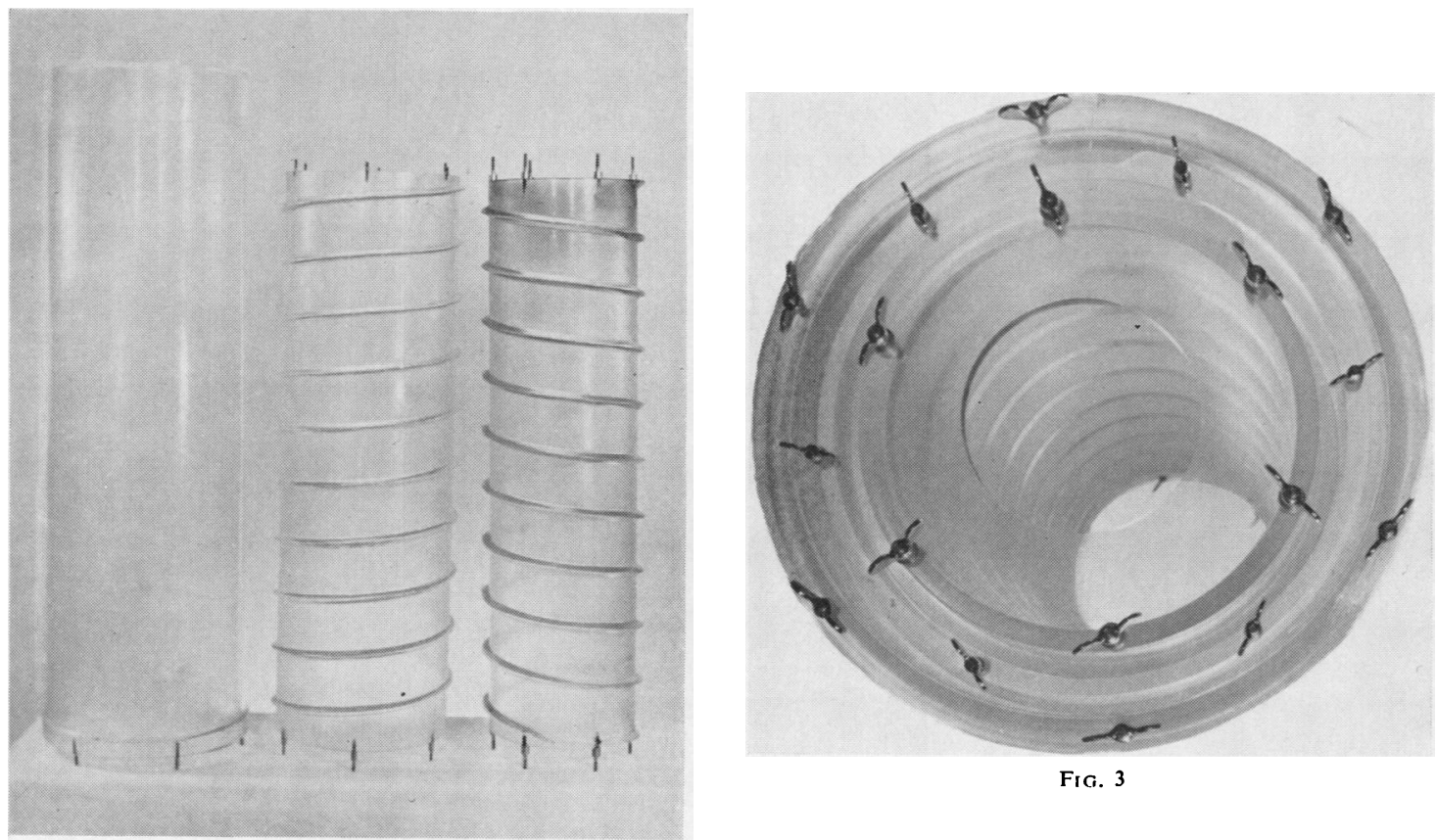

Fig. 3

Fici. 2
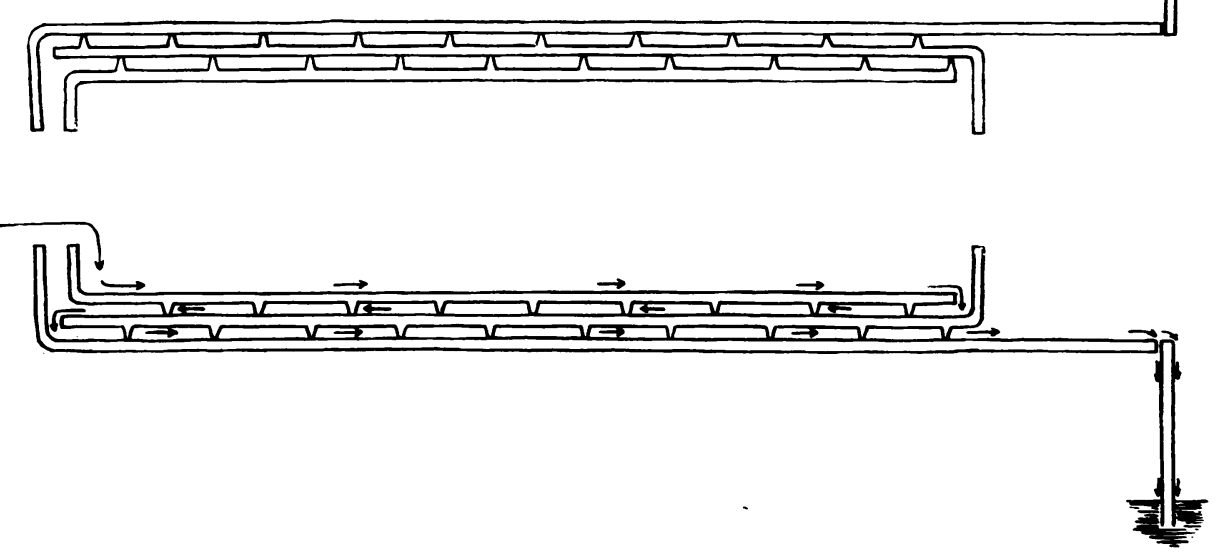

FIG. 4.-Longitudinal section to show passage of blood through oxygenator.

The photographs (Figs. 1 to 3 ) show the machined perspex prototype. In this the ends are fastened on to the cylinders with screws; in the final version the ends will be cast on the cylinders. Fig. 4 is a longitudinal section to show the passage of blood through the oxygenator.

The oxygenator discharges into an arterial reservoir. This is a rectangular box into which the open end of the oxygenator projects through a circular aperture. It contains a delivery plate which is applied to the end of the oxygenator and has a circular hole cut out of it, corresponding in size and position to the end of the oxygenator. Blood leaving the oxygenator passes immediately on to the delivery plate and runs smoothly down both sides of it into the reservoir. The arterial outflow line leaves one side of the reservoir and a wide-bore tube, to act as a shunt with the venous reservoir, leaves the other.

\section{Method of Operation}

Relation of Blood Flow, Rotation Rate, and Residual Blood Volume.-The rate of blood flow through the apparatus depends upon the rate of rotation. If blood is delivered into it at a rate of flow exceeding the maximum for a given rate of rotation it overfills and the blood froths as a result. 


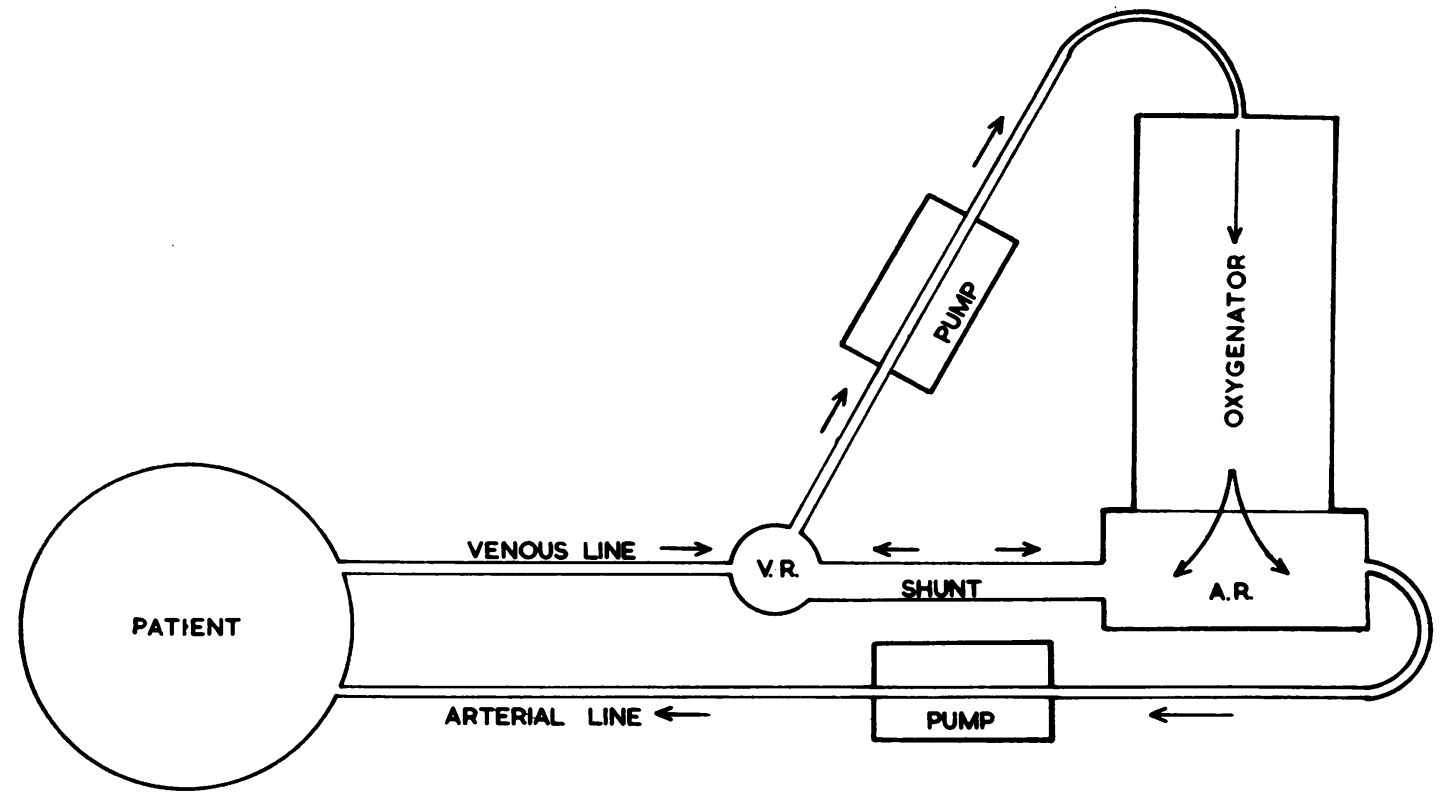

FIG. 5.-Circuit diagram to show accessory circuit.

The volume of blood held up in passage through the oxygenator also varies somewhat according to the rate of flow and the speed of rotation. In practice it has been found best to keep the rate of rotation, the rate of flow, and therefore also the volume of blood held in the oxygenator, constant. Since it is necessary to be able to vary the perfusion rate during a bypass operation an accessory circuit is provided. This consists of (1) a wide-bore shunt between the arterial and venous reservoirs and (2) a pump delivering blood from this venous reservoir to the oxygenator at a constant rate of flow (Fig. 5). The rate of flow through the pump and the oxygenator are set so as slightly to exceed the maximum estimated for the perfusion and remain unchanged throughout. Before bypass the arterial and venous reservoirs are filled with blood and the accessory pump started. Blood circulates from the venous reservoir through the oxygenator into the arterial reservoir and back through the shunt into the venous reservoir. When cardiac bypass is started and blood enters the venous reservoir the level of blood rises in both reservoirs; the arterial pump is then started and blood returned from the arterial reservoir to the patient. It is only necessary to regulate the arterial pump, keeping the blood level constant in the reservoir to ensure that venous return and arterial outflow are balanced.

\section{RESULTS}

Oxygenating Capacity.-Fresh citrated ox blood of approximately $50 \%$ oxygen saturation and at body temperature has been run through the apparatus at a flow rate of 3.5 litres per minute and has been raised to $97 \%$ saturation during passage. The rotation speed necessary to maintain this flow was 84 r.p.m. and the volume of blood held up in the oxygenator was about 1 litre.

Effect on Blood Cells.-Four litres of fresh heparinized blood from human volunteers were recirculated through the oxygenator at $30^{\circ} \mathrm{C}$. at a rate of 1 litre per minute for one hour and samples taken every 15 minutes for plasma haemoglobin, red cell fragility, white cell, and platelet counts. As a control the oxygenator was removed from the circuit and 3 litres of fresh heparinized human blood passed through the pumps only for a similar period. The results are given in Table II. It will be seen that the amount of haemolysis in

TABLE II

EFFECT OF OXYGENATOR ON BLOOD CELLS

\begin{tabular}{|c|c|c|c|c|c|c|}
\hline Test & Circuit & $\begin{array}{c}\text { Before } \\
\begin{array}{c}\text { Circula- } \\
\text { tion }\end{array}\end{array}$ & $\begin{array}{c}\text { After } \\
15 \\
\text { Minutes }\end{array}$ & $\begin{array}{c}\text { After } \\
30 \\
\text { Minutes }\end{array}$ & $\begin{array}{c}\text { After } \\
45 \\
\text { Minutes }\end{array}$ & $\begin{array}{c}\text { After } \\
60 \\
\text { Minutes }\end{array}$ \\
\hline $\begin{array}{c}\text { Plasma } \\
\text { Hb } \\
(\mathrm{mg} . \%)\end{array}$ & $\begin{array}{l}\text { Pump and } \\
\text { oxygenator } \\
\text { Pump only }\end{array}$ & $\begin{array}{l}4 \\
2\end{array}$ & $\begin{array}{l}20 \\
20\end{array}$ & $\begin{array}{l}40 \\
36\end{array}$ & $\begin{array}{l}40 \\
40\end{array}$ & $\begin{array}{l}56 \\
65\end{array}$ \\
\hline W.B.C.s & $\begin{array}{l}\text { Pump and } \\
\text { oxygenator } \\
\text { Pump only }\end{array}$ & $\begin{array}{l}4,400 \\
3,800\end{array}$ & $\begin{array}{l}3,750 \\
4,100\end{array}$ & $\begin{array}{l}4,000 \\
4,000\end{array}$ & $\begin{array}{l}4,200 \\
3,800\end{array}$ & $\begin{array}{l}4,200 \\
4,200\end{array}$ \\
\hline $\begin{array}{l}\text { Plate- } \\
\text { lets }\end{array}$ & $\begin{array}{l}\text { Pump and } \\
\text { oxygenator } \\
\text { Pump only }\end{array}$ & $\begin{array}{l}259,000 \\
225,000\end{array}$ & $\begin{array}{l}242,000 \\
236,000\end{array}$ & $\begin{array}{l}246,000 \\
212,000\end{array}$ & $\begin{array}{l}231,000 \\
221,000\end{array}$ & $\begin{array}{l}240,000 \\
220,000\end{array}$ \\
\hline
\end{tabular}


both experiments is roughly the same and that the effect on the platelets and W.B.C.s was negligible. It can therefore be said that this method of oxygenation does not appear to damage any of the cellular elements of the blood.

Cost of Apparatus.-Further development of this oxygenator depends upon the manufacture of moulds from which the plastic drums can be cast. If these are made of "araldite" a set of three drums capable of being sterilized by heat would cost approximately $£ 15$. Having regard to the other expenses involved in a cardiac bypass operation, this sum is small, and a fresh set of drums could be used for each human case.
The Bristol Aircraft Company have manufactured for us the prototype of this oxygenator and are prepared to make the moulds for casting the final version. We particularly wish to thank Mr. W. A. Baker and Mr. Shumack for their help and advice.

Mr. Garry Meade, instrument technician of the United Bristol Hospitals, made for us several earlier models which were forerunners of the present design and his help throughout has been invaluable.

Our grateful thanks are due to Dr. G. Tovey and Dr. N. F. W. Brueton, who have kindly carried out the haematological work described in this paper.

Finally, we wish to thank the Trustees of the Nuffield Fund for the grant out of which this work was financed. 